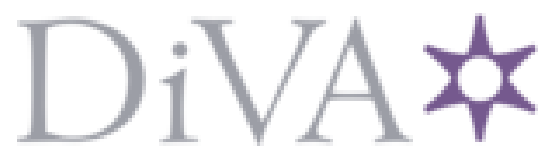

http://www.diva-portal.org

This is the published version of a paper published in Global Environmental Change.

Citation for the original published paper (version of record):

Lövbrand, E., Beck, S., Chilvers, J., Forsyth, T., Hedrén, J. et al. (2015)

Who speaks for the future of Earth?: how critical social science can extend the conversation on the Anthropocene.

Global Environmental Change, 32: 211-218

http://dx.doi.org/10.1016/j.gloenvcha.2015.03.012

Access to the published version may require subscription.

N.B. When citing this work, cite the original published paper.

Permanent link to this version:

http://urn.kb.se/resolve?urn=urn:nbn:se:oru:diva-4384 1 


\title{
Who speaks for the future of Earth? How critical social science can extend the conversation on the Anthropocene
}

\author{
Eva Lövbrand ${ }^{\mathrm{a}, *}$, Silke Beck ${ }^{\mathrm{b}}$, Jason Chilvers ${ }^{\mathrm{c}}$, Tim Forsyth ${ }^{\mathrm{d}}$, Johan Hedrén ${ }^{\mathrm{a}}$, Mike Hulme ${ }^{\mathrm{e}}$, \\ Rolf Lidskog ${ }^{\mathrm{f}}$, Eleftheria Vasileiadou ${ }^{\mathrm{g}}$ \\ ${ }^{a}$ Department of Thematic Studies - Environmental Change, Linköping University, 58183 Linköping, Sweden \\ b Department of Environmental Politics, Helmholtz Centre for Environmental Research - UFZ, Permoserstraße 15, 04318 Leipzig, Germany \\ ' School of Environmental Sciences, University of East Anglia, Norwich Research Park, Norwich NR4 7TJ, UK \\ d Department of International Development, London School of Economics and Political Science, Houghton Street, London WC2A 2AE, UK \\ e Department of Geography, King's College London, K4L.07, King's Building, Strand Campus, London WC2R 2LS, UK \\ ${ }^{\mathrm{f}}$ Environmental Sociology Section, Örebro University, 70182 Örebro, Sweden \\ ${ }^{\mathrm{g}}$ Department of Industrial Engineering E' Innovation Sciences, Technische Universiteit Eindhoven, P.O. Box 513, 5600 MB Eindhoven, The Netherlands
}

\section{A R T I C L E I N F O}

\section{Article history:}

Received 5 November 2014

Received in revised form 27 March 2015

Accepted 28 March 2015

Available online

\section{Keywords:}

Anthropocence

Politics

Global environmental change

Social science

Critical interpretation

Ontology

\begin{abstract}
A B S T R A C T
This paper asks how the social sciences can engage with the idea of the Anthropocene in productive ways. In response to this question we outline an interpretative research agenda that allows critical engagement with the Anthropocene as a socially and culturally bounded object with many possible meanings and political trajectories. In order to facilitate the kind of political mobilization required to meet the complex environmental challenges of our times, we argue that the social sciences should refrain from adjusting to standardized research agendas and templates. A more urgent analytical challenge lies in exposing, challenging and extending the ontological assumptions that inform how we make sense of and respond to a rapidly changing environment. By cultivating environmental research that opens up multiple interpretations of the Anthropocene, the social sciences can help to extend the realm of the possible for environmental politics.
\end{abstract}

(c) 2015 Published by Elsevier Ltd.

\section{Introduction}

In recent years leading environmental scientists have told us that we live in an unprecedented time called 'the Anthropocene'. The Anthropocene concept was coined by the chemist and Nobel Laureate Paul Crutzen and biologist Eugene Stoermer at the turn of the new millennium to describe a new geological era fully dominated by human activity (Crutzen and Stoermer, 2000). Since then it has taken root in scientific and popular discourse and offered a powerful narrative of human resource exploitation, planetary thresholds and environmental urgency. Central to the Anthropocene proposition is the claim that we have left the benign era of the Holocene - when human civilizations have developed

\footnotetext{
* Corresponding author. Tel.: +46011363393.

E-mail addresses: eva.lovbrand@liu.se (E. Lövbrand), silke.beck@ufz.de (S. Beck), jason.chilvers@uea.ac.uk (J. Chilvers), t.j.forsyth@lse.ac.uk (T. Forsyth), johan.hedren@liu.se (J. Hedrén), mike.hulme@kcl.ac.uk (M. Hulme), rolf.lidskog@oru.se (R. Lidskog), E.Vasileiadou@tue.nl (E. Vasileiadou).
}

and thrived - and entered a much more unpredictable and dangerous time when humanity is undermining the planetary lifesupport systems upon which it depends (Rockström et al., 2009; Steffen et al., 2015). In the Anthropocene, we are told, the Cartesian dualism between nature and society is broken down resulting in a deep intertwining of the fates of nature and humankind (Zalasiewic et al., 2010, p. 2231).

In this paper we discuss how the social sciences can engage with this powerful environmental narrative in productive ways. In a time when international science initiatives such as Future Earth are 'calling to arms' and asking environmental scholars across all disciplines to participate in an integrated analysis of the Anthropocene (Palsson et al., 2013), this is a pressing question that has triggered a discussion on the role of social and cultural theory in the study of global environmental change (O'Brien, 2012; Castree et al., 2014; Castree, 2014a). In a number of recent publications, scholars have questioned the marginal and instrumental roles granted to the social sciences and humanities in environmental research and problem-solving. Whereas the Anthropocene concept represents a tremendous opportunity to 
engage with questions of meaning, value, responsibility and purpose in a time of rapid and escalating change (Rose et al., 2012, p. 1), critics maintain that the institutions and networks out of which the Anthropocene concept has emerged (notably the global change research programmes of the International Council for Science, ICSU) to date have failed to bring qualitative questions of this kind to bear on their research activities. In the quest for solutions to urgent collective action problems, the focus has primarily been on means rather than ends and attention has hereby been diverted away from the social and cultural norms, practices and power relations that drive environmental problems in the first place (O'Brien, 2012). As a consequence, the global change research community has been charged of producing a post-political Anthropocene narrative dominated by the natural sciences and focused on environmental rather than social change (Malm and Hornborg, 2014; Castree et al., 2014; Swyngedouw, 2014).

In this paper we draw upon this critique to explore how the social sciences may help to extend the conceptual terrain within which the Anthropocene scholarship currently operates. While we note that the Anthropocene is a concept in the making, we argue that the mainstream story projected by leading environmental scientists in high profile journal articles and conference declarations so far has offered a restricted understanding of the entangled relations between natural, social and cultural worlds. As such it has also foreclosed the conversation on the range of social and environmental futures that are possible, and indeed desirable, in 'the age of man'. In order to push the conversation on the future of Earth in new directions, this paper outlines a research agenda for the social sciences that invites critical engagement with the Anthropocene as a socially and culturally bounded object with many possible meanings and political trajectories. To that end we mobilize the critical and interpretative social sciences. While analytically diverse and sometimes competing, the multiple theoretical traditions that we sort under this label share an interest in thinking creatively and critically about the causes, rationalities, practices and politics of environmental research and policy-making. Rather than accepting the world as we find it, work in this field prompt scholars to reflect upon the ideas, norms and power relations that make up the world and to imagine it anew (for useful examples, see Death, 2014; Bradley and Hedrén, 2014).

In the following we tap into these intellectual resources to critically examine three claims that underpin the proposed advent of the Anthropocene. We call these the post-natural, the postsocial, and the post-political ontology of the Anthropocene. We begin by outlining what characterizes each claim and continue by discussing how social inquiry may help to interpret, and ultimately extend, the cultural, social and political assumptions they rest upon and project. We contend that critical social engagement with the Anthropocene does not promise any immediate solutions to contemporary environmental challenges. The research agenda advanced in this paper is more likely to unsettle the Anthropocene and to pave the way for competing understandings of the entangled relations between natural and social worlds. Rather than leading astray, however, we argue that such interpretative multiplicity offers an important alternative to the contemporary quest for integrated and solutions-oriented environmental research (Future Earth, 2013). In order to facilitate the kind of political mobilization required to meet the complex environmental challenges of our times, the social sciences need to do more than ask which 'products and services' societal stakeholders need in the transition to sustainability (Future Earth, 2014). A more pressing analytical task lies in exposing and challenging the underlying cultural and social assumptions that inform how we collectively makes sense of and respond to a changing environment. Only when extending the conversation on the future of Earth to a broader set of knowledge traditions and communities is it possible, we argue, to harness the critical potential of the Anthropocene and hereby extend the realm of the possible for environmental politics. Herein lies a tremendous opportunity for social science.

\section{The advent of the Anthropocene}

The Anthropocene is far from a settled concept. The growing number of publications on the topic suggest that it is an idea in the making that has sparked diverse interdisciplinary conversations on the state of the global environment, the direction of late capitalist society, and the possibility of a self-contained, rational human subject (see, for instance, Steffen et al., 2015; Malm and Hornborg, 2014; Wakefield, 2014). While the Anthropocene clearly has the potential to draw 'the humanities and the natural and social sciences into dialogue in new and exciting ways' (Rose et al., 2012, p. 4), the concept has its home in the environmental sciences and is dominated by a persuasive science narrative of escalating humaninduced environmental change. Steffen et al. (2011a) trace the idea of a human dominated planet back to early observations of human alterations of land and sea found in volumes such as George Perkins Marsh's The Earth as Modified by Human Action (1874), Eduard Seuss' The Face of the Earth (1906), and Vladimir Vernadsky's Biosphere and Noosphere (1945). Long before Nobelprize winning chemist Paul Crutzen and biologist Eugene Stoermer coined the Anthropocene concept in a global change newsletter in year 2000, the environmental consequences of human activities such as land clearing, water usage and fossil fuel burning were well documented and debated within the environmental sciences (Vitousek et al., 1997). When integrated Earth System models were introduced and developed by international science programmes such as the International-Geosphere-Biosphere Programme (IGBP) in the late 1980s, these findings were compiled and aggregated into a global understanding of human-induced environmental change (Uhrqvist and Lövbrand, 2014).

In the following we examine three ontological claims emerging from these coordinated research efforts and that now form the ground for the scientific Anthropocene narrative. The assumptions we make about this narrative rest upon a close reading of conference declarations such as the Amsterdam Declaration on Global Change (2001) and the State of the Planet Declaration (2012), as well as journal articles produced by leading proponents of the Anthropocene concept such as Paul Crutzen, Will Steffen and Jan Zalasiewic. While the significance and meaning of the Anthropocene remains contested and unsettled, we argue that there is a distinct story emerging from the global environmental change research community that is affecting how the conversation on the future of Earth currently is unfolding.

\subsection{The post-natural ontology of the Anthropocene}

The deep intertwining of natural and human systems is at the heart of the scientific Anthropocene narrative (Oldfield et al., 2014). As clarified by Zalasiewic et al. (2010, p. 2228) the Anthropocene concept was coined in a time of 'dawning realization that human activity was indeed changing the Earth on a scale comparable with some of the major events of the ancient past.' In Stoermer's and Crutzen's pioneering paper from year 2000, climate change emerges as the primary signal of the Anthropocene. The rising atmospheric concentrations of greenhouse gases resulting from human land use change and fossil fuel burning here symbolize the ability of 'civilized man' to alter natural systems to the extent that they cannot be considered 'natural' anymore. In other studies the strong human 'footprint on the planet' (Vitousek et al., 1997) is attributed to land transformations through forestry and agriculture, biodiversity loss through land clearing and the introduction of alien species, the damming of rivers, the 
terraforming effects of the world's megacities or the introduction of information and geoengineering technologies (Steffen et al., 2004; Zalasiewic et al., 2010; Galaz, 2014). Taken together these Anthropocene analyses suggest that humankind has become a global scale force with the ability to fundamentally reshape the planet. The dominant influence of humanity has pushed the Earth into a new geological era "when natural forces and human forces are so intertwined that the fate of one determines the fate of the other' (Zalasiewic et al., 2010, p. 2231).

Barry et al. (2013) refer to this fusing together of human and non-human histories as the post-natural ontology of the Anthropocene. The 'humanization' of the natural environment implied by the advent of the Anthropocene suggests a crossing of the humannature divide inherited from the Enlightenment era. In the Anthropocene, nature is domesticated, technologized and capitalized to the extent that it can no longer be considered natural. As proclaimed by Crutzen and Schwägerl (2011) '(i)t's no longer us against "Nature". Instead, it's we who decide what nature is and what it will be'. While this conquest of the natural world can be interpreted as the epitome of human rationality and progress, the Anthropocene is not automatically 'a hyperbolic narrative of totalized humanity' (Wakefield, 2014, p. 12). For many humanist scholars 'the Anthropocene is as much about the decentering of humankind as it is about our rising geological significance' (Clark, 2014 , p. 25 italics in original). It is a concept that emphasizes humanity's material dependence, embodiment and fragility, and hereby invites us to rethink long-held assumptions about the autonomous, self-sufficient human subject that begins and ends with itself (Wakefield, 2014). Interestingly, however, leading advocates of the Anthropocene concept have to date failed to take on board the ontological implications of their proposed age of man'. Although the Anthropocene is said to represent the 'end of nature' (cf. McKibbin, 1989), an era when 'nature is us' (Crutzen and Schwägerl, 2011), the scientific Anthropocene narrative continues to portray nature as an object external to society with 'natural' limits and tipping points that can be discerned, quantified and managed with some degree of scientific objectivity (Steffen et al., 2015). As a consequence, humankind is both inserted into nature and re-elevated above it (Baskin, 2014, p. 4).

We believe that the social sciences are well equipped to address this tension by further socializing the Anthropocene concept. Across fields such as political ecology (e.g. Castree, 2014b), science and technology studies (STS) (Latour, 2004; Jasanoff, 2004), and gender studies (Alaimo, 2010) social constructivist scholars have for some time critically interrogated how sedimented representations of nature and society are constituted or co-produced as hybrid nature-cultures. A central ontological assumption running across this diverse critical-interpretative scholarship is that natures never come ready made. As suggested by Latour (1993) nature will always be a 'quasi-object' that is real in a material sense, and yet discursively narrated and socially mediated. From this interpretative horizon there is no pristine or 'natural' nature against which the advent of the Anthropocene can be analyzed. Nature is as much a socio-cultural phenomenon as a biophysical one that comes into being and gains meaning through representational practices and technologies (Baldwin, 2003). The question to ask about nature is thus not what it is or how it changes in an absolute or final sense, but how it is enacted through scientific knowledge practices and with what material and political effects.

Three epistemological implications flow from this more radical post-natural position that may help to push the conversation on the future of Earth in new directions. First, the interpretative social sciences insist that knowledge always is situated, embodied and contingent on pre-commitments and imaginaries of the future (Haraway, 1988). The needs, claims and actions of the human observer are always inseparable from the social, cultural and material context in which s/he is embedded. This means that unmediated representations of nature are as unattainable as they are undesirable. In their place we find a reflexive and situated epistemology that invites us to revisit who speaks for nature, what we mean by nature, and to denaturalize what is given to us as natural (Castree, 2014b). Second, subject/object distinctions break down. The repositioning of the knowing subject as a self-conscious part of nature invites a constant reflection on the ethical assumptions that shape our knowledge/value-commitments and those of others (Chilvers, 2013). It is through such reflexivity that an attitude of humility can be fostered and room is made for the exercise of wisdom, a long-treasured human virtue which brings together knowledge and action in relational settings (Hulme, 2014).

Finally, a more radical post-natural scholarship is attentive to the material effects of particular nature representations. In some STS debates, especially in the USA, the 'co-production' concept has been advanced to critically interrogate how ways of seeing and engaging with nature, often originating from the domains of science and technology, shape how the environment is construed and acted upon in social and political life (Jasanoff, 2004). By asking whose nature is being represented and what the material effects of such representations are, this is a literature that has sought to denaturalize the privileged gaze of science and hereby open up for multiple ways of knowing and experiencing nature (Jasanoff and Long Martello, 2004; Litfin, 1997). To interpret and interrogate the possibilities of the Anthropocene from this more radical postnatural perspective opens up a plurality of nature framings, knowledges and cosmologies. Emphasis is placed on mapping and accounting for multiplicity as opposed to producing stable accounts of environmental change everyone can rally behind (e.g. Hulme, 2010; Whatmore, 2009; Stirling, 2011).

\subsection{The post-social ontology of the Anthropocene}

The Anthropocene puts humans at the centre of global environmental change. It is a story of 'the Anthropos' that has conquered the planet and now is humanizing the natural environment in dangerous and unforeseeable ways. The conception of humanity as a geological force that is altering the 'natural' dynamics of the Earth is effectively outlined in the Amsterdam Declaration on Global Change and the State of the Planet Declaration, jointly signed by the chairs of the IGBP, the International Human Dimensions Programme on Global Enviromental Change (IHDP), the World Climate Research Programme (WCRP) and DIVERSITAS in 2001 and 2012 respectively. Reporting from several decades of coordinated global environmental change research, the two conference declarations highlight how human-driven changes to the Earth's land surface, oceans, coasts and atmosphere are cascading through the Earth System in ways that now endanger the Earth's environment and its inhabitants (Moore et al., 2002). "Consensus is growing that we have driven the planet into a new epoch, the Anthropocene, in which many Earth-system processes and the living fabric of ecosystems are now dominated by human activities" (Brito and Stafford Smith, 2012). Given this emphasis on the human dimensions of environmental change it is remarkable, and highly paradoxical, that the resulting Anthropocene narrative to date has told us so little about societal dynamics (Palsson et al., 2013; Malm and Hornborg, 2014). In the two conference declarations, humankind emerges mainly as an interconnected subsystem to the larger Earth System, and as such, a single force (of nature!), a generalized determinant of global change.

In this paper we refer to this contracting of social diversity and difference into a single path for humanity as the post-social ontology of the Anthropocene. As noted by Malm and Hornborg (2014) the proposed 'geology of mankind' is not grounded in an 
analysis of social relations, but in a naturalized and aggregated account of the human species. Luke (2009) interprets this tendency to universalize 'the human' into a post-social category as an effect of the prevailing quantitative metric in global environmental change research. In order to map, monitor and ultimately manage human-induced environmental change, the diverse and dynamic possibilities for different societies and economies are by necessity narrowed and simplified. This interpretation is confirmed by several social scientists involved in global environmental change research. O'Brien and Barnett (2013, p. 378), for instance, bear witness of a certain orthodoxy with respect to the object of study and approach to knowledge within international global change research institutions and programmes. By framing environmental change within the context of Earth System science, these institutions have fostered an epistemology that is focused on understanding and predicting environmental changes through integrated assessments and modelling studies. Whereas these efforts have increased the understanding the biophysical processes underpinning a changing environment, O'Brien and Barnett (2013, p. 381) note that 'the social drivers and human consequences are often overgeneralized (for example, in sweeping claims about impacts on women and the poor) or deterministic (as in accounts of climate change forcing mass migration and warfare).'

We contend that a deeper involvement of the social sciences in the study of the Anthropocene will help to overcome this postsocial ontology. When embedding the Anthropocene in the social fabric, the human drivers, motivations and implications of environmental change can no longer be generalized, but will by necessity multiply. Numerous studies have illustrated how global representations of environmental problems such as climate change are complicated and challenged when they meet the local and every-day life of particular people and places (Fogel, 2004; Liverman, 2009). After all, human beings are always and everywhere embedded. Individuals, groups and organizations live in a world of biophysical properties and material artefacts, but also in a socio-cultural world of meanings and motivations (Jasanoff, 2010). People and social groups do not develop their own goals, values and preferences apart from those that already exist in society, but in close relation to these. In order to explore the dynamics and trajectory of the Anthropocene, we thus need to understand the situated social drivers and implications of 'human activities' such as land-use change or energy use, and the meanings and forms of political agency they produce at particular times.

A socially embedded Anthropocene scholarship also acknowledges social and political differentiation. Ever since Agarwal and Narain (1991) illustrated the inequalities embedded in global representations of climate change, social scientists have insisted that we take seriously the power relations that grant individuals, groups and communities different abilities to challenge and break with entrenched socio-ecological arrangements (Jasanoff and Long Martello, 2004). As outlined by Baskin (2014, p. 8) the Indian subsistence farmer or the Peruvian slum-dweller are clearly very differentially responsible for ecological devastation and planetary overshoot than inhabitants of the rich world. Neither can their vulnerabilities be compared. Malm and Hornborg (2014) draw upon the experiences of hurricane Katrina in black and white neighbourhoods of New Orleans, and sea level rise in Bangladesh and the Netherlands, to illustrate the uneven distribution of environmental risks and vulnerabilities across all scales of human society. When linking environmental change to social categories such as class, race, gender, power and capital we thus find that the challenges of the Anthropocene are far from universal. Rather, they emerge from different socio-political settings, produce different kinds of vulnerabilities and will therefore most likely generate different kinds of political responses (Liverman, 2009; O'Brien and Barnett, 2013).

\subsection{The post-political ontology of the Anthropocene}

The Anthropocene has to date not been presented as a hopeful story of human development and purpose. The dominant scientific narrative is rather one of the urgency and crisis, with deadlines to meet and tipping points beyond which interventions are 'too late'. Steffen et al. (2007), for instance, stage the Anthropocene as a state of exception when human resource exploitation and degradation has become so pervasive and profound that it rivals some of the great forces of nature. It is a dangerous and unpredictable age, we are told, when human activities have pushed 'the Earth System outside the stable environmental state of the Holocene, with consequences that are detrimental or even catastrophic for large parts of the world' (Rockström et al., 2009, p. 472). While Crutzen and Stoermer originally linked this new era to the industrial revolution in 18th Century Europe, Steffen et al. (2007) primarily situate the Anthropocene in the post-World War II era when 'the human enterprise switched gear'. During this period the human population has grown faster than at any previous time in history; industrialization has gained irresistible momentum; the world economy has expanded in unexpected ways; transport and ITtechnology has rapidly transformed mobility and human connectivity (Steffen et al., 2007, p. 618). An unintended side-effect of this 'great acceleration' in social and economic development, so it is argued, is dramatic environmental change which now threatens the planetary life-support systems upon which human civilization depends (ibid).

In order to counter an immanent ecological catastrophe, leading Anthropocene advocates have begun to define safe planetary boundaries beyond which the Earth System will no longer function in a stable, Holocene-like state (Rockström et al., 2009; Steffen et al., 2015). Interestingly, this invocation of biophysical limits for social and economic development is seldom coupled with potent suggestions for social and political transformation (for an interesting exception, see Dearing et al., 2014). The fundamental challenges to societal organization posed by the Anthropocene are, paradoxically, to be countered by many of the same institutions that have allowed the recent human conquest of the natural world. Among the proposals for 'Earth stewardship' we find international expert institutions, carbon pricing mechanisms, green technologies and international environmental treaties (Chapin et al., 2011; Steffen et al., 2011b; Biermann, 2012). We refer to this paradoxical relationship between environmental apocalyptic thought on the one hand, and institutional status quo on the other, as the postpolitical ontology of the Anthropocene. Swyngedouw (2013) defines post-politics as a socio-political arrangement that replaces ideological contestation and struggles by techno-managerial planning. It is a condition where the articulation of divergent and conflicting trajectories for socio-political development is replaced by a normative consensus around common humanitywide action in face of pending environmental catastrophe. When disagreement is allowed, suggests Swyngedouw (2013), it is primarily with respect to the choice of technologies, the detail of the managerial adjustments, and the urgency of their timing and implementation.

This post-politics of environmental urgency, we argue, is closely related to the lack of critical social and political analyses of the Anthropocene. When the complex environmental challenges of our times are accounted for in aggregated terms, we lose sight of the situated conflicts, warped distribution of wealth and unequal power relations that engine 'the great acceleration'. As a consequence, the space for political contestation, debate and reorientation is also restricted. We believe that a deeper involvement of critical social science in global environmental change research represents an important step out of this post-political situation. Across fields such as political ecology, post-colonial studies and 
green political thought we find many examples of critical, interpretative and normative social theorizing that seeks to push the boundaries of environmental thought and policy practice (for examples, see Bradley and Hedrén, 2014; Death, 2014; Castree, 2014 b). While work in this field is diverse and includes both postcapitalist, post-colonial and post-modern narratives, it shares the power of imagination and the will to change. Instead of accepting the post-political formulation of Anthropocene as 'the apocalyptic end to all things' (Dalby, 2013, p. 191), critical social inquiry may both help do diagnose and destabilize dominant social-ecological arrangements (e.g. ecological modernization, green growth, ecosystem services) and to open up conversations on political alternatives. Merely analyzing other social-ecological futures does not, of course, guarantee transgression of the ideologies, institutions and power relations that bring about environmental change. Such analyzes can, however, make the impossible seem possible and hereby push environmental politics in new and unexpected directions.

\section{Extending the conversation on the future of Earth}

The proposition that we have left the Holocene and entered into a new geological epoch fully dominated by human activity is a challenging one that has paved the way for new forms of research coordination and funding. In the State of the Planet Declaration we learn that 'that challenges facing a planet under pressure demand a new approach to research that is more integrative, international and solutions-oriented' (Brito and Stafford Smith, 2012). In order to account for the dynamics of the planetary life support system as a whole, environmental scholars across the natural and social sciences are now asked to find new ways of collaboration that make it possible to put the various pieces of the Earth System together in innovative and incisive ways (Steffen et al., 2004, p. 32). The basic premise of this bridging of research traditions, explain Ignaciuk et al. (2012), is that no single discipline can adequately account for the complex environmental challenges of our times. In order to fully understand why and how the Earth's environment is changing, and hereby foster adequate policy responses the argument goes, coordinated appraisals of the Anthropocene are required.

A step in this direction was taken in 2001 when the Earth System Science Partnership (ESSP) was established by the International Council of Science (ICSU). Responding to mounting calls for coordinated Earth System research, the partnership reached out to the global change research networks organized around the WCRP, IGBP, IHDP and DIVERSITAS and brought about joint research projects and agendas. In time for the UN Conference on Sustainable Development in Rio de Janeiro (Rio +20) in summer 2012, the ESSP transitioned into a more institutionalized programme for integrated Earth System research called Future Earth. Whereas scientific integration and coordination remain lead motifs of this new research programme, policy relevance has surfaced as an equally important mandate. In order to effectively address the urgent environmental challenges of our times, Future Earth seeks to codesign solutions with societal stakeholders and hereby begin the transition to global sustainability (Future Earth, 2013, p. 10).

In this quest for coordinated and solutions-oriented environmental research, Future Earth has called for a deeper involvement of the social sciences. Scholars across political science, human geography, sociology and economics are today asked to align with global environmental change research agendas and hereby participate more fully in the strong and immediate commitment 'to actions that reduce the known risks to Earth's life support system' (Stafford-Smith et al., 2012, p. 5; Palsson et al., 2013). In the following we outline three entry points to this collaborative endeavour for the critical and interpretative social sciences. While we insist that critical social inquiry has much to offer (and learn from) global environmental change research, the research agenda advocated here does not strive for integrated accounts of the Anthropocene nor will it offer any immediate solutions to the pressing environmental challenges of the day. A more important role for the social sciences, we argue, is to harness the critical potential of the Anthropocene and hereby create opportunities to reason differently about the future of Earth.

\subsection{Radicalize the post-natural}

Firstly we contend that a critical Anthropocene research agenda invites a serious engagement with the epistemological implications of a post-natural ontology. The advent of a truly entangled socio-physical nature emerges as a reason to radically challenge and rethink the possibility and desirability of unified scientific accounts of environmental change, and to experiment with multiple and situated ways of seeing and acting upon the hybrid world that we now inhabit. We recognize that the proposed research agenda of Future Earth takes steps in this direction through its focus on co-production and co-design. By aligning environmental research agendas with the knowledge needs of societal user groups, Future Earth aims to push the global environmental change community towards more transparent, salient and solutions-oriented forms of knowledge (Future Earth, 2013, p. 21). According to the initial design document of Future Earth (2013), this effort to open up the research process to stakeholders across the public, private and voluntary sectors is driven by a desire to deliver the knowledge that society needs to address the complex environmental problems of our times. While the ambition to close the gap between knowledge and action certainly is an important one, we contend that this should not be the only (or even primary) role for the social sciences in the continued study of the Anthropocene. A more radical interpretation of the co-production concept suggests that we also need to foster research that critically interrogates how established nature concepts and problem representations come about, how they are maintained by networks of influence and, ultimately, how they condition the kinds of solutions that are deemed necessary at particular times.

The questions posed by the 'end of nature' are hereby both epistemological and political. A radical post-natural scholarship will by necessity challenge the modern concept of Nature as a pure, singular and stable domain that can be accounted for through systemic observation and scientific explanation (Lorimer, 2012). By cultivating an epistemology that situates environmental research in relation to its social and material setting, the social sciences may instead help to illustrate that what counts as nature and natural is historically and culturally contingent and therefore subject to change. Many critical scholars insist that such conceptual critique is necessary in order to resist the modernist dream of mastery as well as an environmentalist recourse to nature as a source of moral value and ethical instruction (Wapner, 2014). To acknowledge the impossibility of unmediated representations of environmental problems may also open up conversations on the future of Earth to alternative ways of seeing and living with nature, embedded in local cultural practices and knowledge-making traditions (Hulme, 2010). The possibilities of such conversations are currently explored and debated in relation to the design of the Intergovernmental Platform for Biological Diversity and Ecosystem Services (IPBES) (Beck et al., 2014). In these debates scholars have pointed at the opportunities of connecting organized global biodiversity knowledge to local scales of meaning (Turnhout et al., 2012).

To devise research agendas and expert institutions that allow local knowledge holders to rename, reclaim and redefine 
environmental research is, of course, a challenging task that does not promise better or more complete understandings of environmental change. Haraway (1988) reminds us that the vision of the less powerful by no means is innocent. To experiment with multiple knowledge-ways should instead be approached as a critical practice that may help to contextualize the formation of environmental knowledge in relation to power relations, and hereby foster reflection on whose knowledge that defines, shapes, and names the world (Tuhiwai Smith, 1999).

\subsection{Highlight social diversity and difference}

Secondly, we suggest that a critical Anthropocene research agenda will resist unified accounts of 'the human' and instead work to situate people and social groups in the rich patterns of cultural and historical diversity 'that make us into who we are' (Rose et al., 2012 , p. 2). In order to foster environmental research that is attentive to 'space, place, politics, power and culture' (O'Brien, 2012, p. 593) it is important, we argue, to question the globalizing instinct of standardized research templates and integrated research questions. Attempts to account for the human signal in the Earth System through integrated assessments and modelling studies may indeed be driven by a genuine concern for the planetary life support system as a whole. However, they run the risk of producing an empty view of humanity that tells us little about the lived experiences, fears, vulnerabilities, ideas and motivations of real people, in real places. Environmental scholars across the social sciences have for long illustrated how 'the global view' of environmental research renders human beings invisible, both as agents and victims of environmental destruction (Litfin, 1997; Jasanoff, 2010). 'In short, the Anthropocene reveals the power of humans, but it conceals who and what is powerful and how that power is enacted' (Baskin, 2014, p. 8).

To question the homogenizing effects of scientific integration and coordination, we argue, is an important step in the reengagement with the Anthropocene as a multiple object with different meanings and unequal consequences for particular places and social groups. The social research agenda proposed here will thus challenge representations of environmental problems that are 'remote or detached from the diverse geographies of personal or collective history and culture' (Hulme, 2010, p. 5). The advent of the Anthropocene may indeed be a common concern of humankind, but can never be addressed at 'the species level' (Dalby, 2013). In order to render the concept meaningful, we need to examine how a changing environment is interpreted, lived and enacted across multiple socio-political contexts and tied to nonmaterial values such as identity, inclusion, and belonging (O'Brien and Barnett, 2013, p. 382). For example, glaciers and forests should be understood not solely in terms of mass balances or carbon budgets, but also in relation to their local cultures and histories (Cruikshank, 2001; Fogel, 2004). This is an important analytical task if we are to understand the many, and often conflicting, social divers, impacts, risks of and responses to environmental change. To recognize that people's experiences of nature differ may help us to reposition 'the human' as a heterogeneous social and political subject and hereby re-connect the Anthropocene to 'the realm of immediacy where meaningful action is possible and most likely to be effective' (Litfin, 1997, p. 38).

\subsection{Reintroduce the political}

Finally, the Anthropocene research agenda advocated here approaches the recent 'geology of mankind' as an opportunity to rethink the political and hereby challenge the managerial impulse of integrated global environmental research. Instead of accepting the scientific staging of the Anthropocene as a planetary emergency and shared humanitarian cause beyond political dispute (Rockström et al., 2014), a critical social analysis of the Anthropocene helps us to rethink engagements with natures (in the plural) as political acts that can yield very real ideological effects (Baldwin, 2003). We agree with Swyngedouw that the apocalyptic vocabulary of the scientific Anthropocene narrative calls for a profound re-scripting of nature in political terms. "The question is not any longer about bringing environmental issues into the domain of politics as has been the case of now but rather about how to bring the political into the environment' (Swyngedouw, 2013, p. 2).

To re-politicize the Anthropocene, we argue, means fostering a vibrant public space where manifold and divergent socio-ecological relations and nature concepts can be exposed and debated. In order to enable such constructive politics of the environment, environmental scholars need to demonstrate that the Anthropocene is not the end of politics. As proclaimed by Dalby (2013, p. 191) '(t)he Anthropocene isn't the terminal phase, it's the next phase!' We believe that the social sciences can help to open up new possibilities for environmental debate by illustrating that there is nothing foundational in nature that needs, demands or requires sustaining (Swyngedouw, 2014, p. 28). Rather than maintaining the ideal of a 'natural' or 'sustainable' nature that can give us guidance on how to conduct our collective lives (Wapner, 2014), it is important to ask critical questions about the kinds of environments we wish to inhabit and the kinds societies we want to produce. For such new social arrangements to materialize, the social sciences need to cultivate political thought that extends beyond 'the products and services' demanded by societal stakeholders in the transition to sustainability (Future Earth, 2014). 'Imaginative breakthroughs' and 'effective solutions' that match the complexity of contemporary environmental problems (Stafford-Smith et al., 2012) will not primarily derive from solutions-oriented environmental research. More promising and urgent, we argue, are efforts to open conceptual and political space where a diversity of green diagnoses, comprehensions and problematizations can be debated and contested (Bradley and Hedrén, 2014, p. 4).

\section{Conclusions}

The Anthropocene is a rich, potent and challenging concept that now is engaged with across diverse academic fields. In this paper we have primarily discussed interpretations emerging from the global environmental change research community. While this diverse interdisciplinary scholarship does not easily speak with one voice, we have argued that the recent strive to integrate and coordinate environmental research agendas has resulted in a distinct scientific narrative that now is shaping conversations on the future of Earth. Central to this Anthropocene narrative is the claim that humankind has become a global scale force with the ability to fundamentally reshape the planet. In a time when the human imprint is everywhere, we have learned that nature is 'being anthroposized at high speed' (Crutzen and Schwägerl, 2011).

Whereas the scientific Anthropocene narrative mobilizes ample empirical evidence of this proclaimed 'end of nature', we have argued that it is not followed by an equally thorough reconceptualization of the hybrid world we now inhabit. Rooted in a quantitative and positivist research paradigm, the dominant story continues to reproduce nature as an object external to society that is possible to know, monitor and manage from afar. This 'ontological priority of nature' (Wapner, 2014, p. 38) is coupled with an equally naturalized view of humankind. By imagining 'the Anthropos' as a singular geological force - a unitary subsystem to the larger Earth System - leading advocates of the Anthropocene concept have drawn 'the human' into nature but failed to account 
for 'the multiplicity and unequal social values, relations, and practices of power that accompany actual humans' (Baskin, 2014, p. 8). This tendency to downplay the social dynamics of environmental change does not only lead to generalized and disembodied accounts of human agency. It also runs the risk of producing a post-political narrative that invites techno-managerial planning and expert administration at the expense of democratic debate and contestation.

We believe the social sciences are well equipped to push the idea of the Anthropocene in new and more productive directions. Interpretation, differentiation and re-politicization represent central traits of this next generation of Anthropocene scholarship, in which a plurality of actors are welcomed to deconstruct established frames of the planet and its inhabitants and to experiment with new ones. It is promising to note that conversations of this kind now are unfolding in diverse academic settings. Across the humanities and social sciences, scholars are adopting the Anthropocene concept to raise critical questions on environmental politics, culture, identity and ethics. It remains to be seen to what extent these questions will inform the global environmental research that currently is developed and institutionalized by Future Earth. Efforts to extend the conversation on the future of Earth to new knowledge traditions and communities means that established research institutions and networks will have to revisit their ontological and epistemological commitments and be ready to experiment with new ones. This is an uncomfortable and challenging task that is unlikely to foster any immediate responses to the knowledge demands from societal stakeholders. Constructive exchange across scholarly pursuits involves a sustained interrogation of, and reflexive sensibility to, taken-forgranted assumptions of just what is at stake in the Anthropocene.

Rather than leading astray, we have in this paper argued that such interdisciplinary interventions offer a necessary complement to the contemporary quest for integrated and solutions-oriented environmental research. In order to turn the Anthropocene into a critical event and a compelling story of social change, it is important to revisit and debate the cultural and social assumptions that inform how we collectively make sense of and respond to a changing environment. While grounded in interpretative-analytical critique, the research agenda outlined in this paper is thus intended as a constructive project that will broaden the range of reflexively engaged roles available to the social sciences in the continued study of nature's and society's entanglement.

\section{Acknowledgements}

This paper builds upon the expert forum 'Nested Networks: Between wishful thinking, empirical evidence and practical relevance', held in Leipzig Germany in 2013. It was funded by the research project 'Novel Forms of Governance by Nested Networks (NESNET)' funded by the German Ministry for Education and Research, Funding Initiative "Research on the Relationship between Science, Politics and Society" (KZ 01UZ1003). The authors acknowledge the financial support provided by the Linköping University Research Fellow Programme.

\section{References}

Agarwal, A., Narain, S., 1991. Global Warming in an Unequal World. Centre for Science and the Environment, New Delhi.

Alaimo, S., 2010. Bodily Natures. Science, Environment and the Material Self. Indiana University Press, Bloomington.

Baldwin, A., 2003. The nature of the boreal forest: governmentality and forestnature. Space Cult. 6 (4), 415-428.

Barry, J., Mol, A., Zito, A., 2013. Climate change ethics, rights, and policies: an introduction. Environ. Polit. 22 (3), 361-376.

Baskin, J., 2014. The Ideology of the Anthropocene? MSSI Research Paper No. 3. Melbourne Sustainable Society Institute, the University of Melbourne.
Beck, S., Borie, M., Chilvers, J., Esguerra, A., Heubach, K., Hulme, M., Lidskog, R., Lövbrand, E., Marquard, E., Miller, C., Nadim, T., Neßhöver, C., Settele, J. Turnhout, E., Vasileiadou, E., Görg, C., 2014. Towards a reflexive turn in the governance of global environmental expertise. The cases of the IPCC and the IPBES. GAIA - Ecol. Perspect. Sci. Soc. 23 (2), 80-87.

Biermann, F., 2012. Planetary boundaries and earth system governance: exploring the links. Ecol. Econ. 81, 4-9.

Bradley, K., Hedrén, J., 2014. Green Utopianism: Perspectives, Politics and MicroPractices. Routledge, London/New York.

Brito, L., Stafford Smith, M., 2012. State of the Planet Declaration. From the Conference Planet Under Pressure in London 2012. Available at: http://www. planetunderpressure2012.net/pdf/state_of_planet_declaration.pdf.

Castree, N., 2014a. The Anthropocene and the environmental humanities: extending the conversation. Environ. Humanit. 5, 233-260.

Castree, N., 2014b. Making Sense of Nature. Routledge, London/New York.

Castree, N., Adams, W., Barry, J., Brockington, D., Büscher, B., Corbera, E., Demeritt, D., Duffy, R., Felt, U., Neves, K., Newell, P., Pellizzoni, L., Rigby, K., Robbins, P., Robin, L., Bird Rose, D., Ross, A., Schlosberg, D., Sörlin, S., West, P., Whitehead, M. Wynne, B., 2014. Changing the intellectual climate. Nat. Clim. Change 4, 763-768.

Chapin, S., Power, M., Steward, T., Pickett, A., Freitag, A., Raynolds, J., Jackson, R.B., Lodge, D.M., Duke, C., Collins, S.L., Power, A.G., Bartuska, A., 2011. Earth stewardship: science for action to sustain the human-earth system. Ecosphere 2 (8), 1-20.

Chilvers, J., 2013. Reflexive engagement? Actors, learning and reflexivity in public dialogue on science and technology. Sci. Commun. 35 (3), 283-310.

Clark, N., 2014. Geo-politics and the disaster of the Anthropocene. Sociol. Rev. 62S1, $19-37$.

Cruikshank, J., 2001. Glaciers and climate change: perspectives from oral tradition. Arctic 54 (4), 377-393.

Crutzen, P.J., Stoermer, E.F., 2000. The "anthropocene". Glob. Change Newsl. 41, $17-18$.

Crutzen, P., Schwägerl, C., 2011. Living in the anthropocene: towards a new global ethos. Yale Environ. 360. Available at: http://e360.yale.edu/feature/ living_in_the_anthropocene_toward_a_new_global_ethos/2363.

Dalby, S., 2013. Biopolitics and climate security in the Anthropocene. Geoforum 49, 184-192.

Dearing, J., Wanga, R., Zhang, K., James, G., Dyke, J.G., Haberl, H., Hossain, M.S., Langdon, P.G., Lenton, T.M., Raworth, K., Brown, S., Carstensen, J., Cole, M.J., Cornell, S.E., Dawson, T.P., Doncasterm, P., Eigenbrodm, F., Florke, M., Jeffers, E., Mackay, A.W., Nykvist, B., Poppy, G.M., 2014. Safe and just operating spaces for regional social-ecological systems. Glob. Environ. Change 28, $227-$ 238

Death, C., 2014. Critical Environmental Politics. Routledge Intervention Series New York.

Fogel, C., 2004. The local, the global and the Kyoto Protocol. In: Jasanoff, S., LongMartello, M. (Eds.), Earthly Politics. Local and Globa in Environmental Governance. The MIT Press, Cambridge, MA

Future Earth, 2013. Future Earth Initial Science Report. International Council of Science, Paris.

Future Earth, 2014. Strategic Research Agenda 2014. Priorities for a Global Sustainability Research Strategy. International Council for Science, Paris.

Galaz, V., 2014. Global Environmental Governance, Technology and politics: The Anthropocene Gap. Edward Elgar Publishing, Cheltenham.

Haraway, D.J., 1988. Situated knowledges: the science question in feminism and the privilege of partial perspective. Fem. Stud. 14 (3), 575-599.

Hulme, M., 2010. Problems with making and governing global kinds of knowledge. Glob. Environ. Change 20, 558-564.

Hulme, M., 2014. Climate change and virtue: an apologetic. Humanities 3 (3), 299-312.

Ignaciuk, A., Rice, M., Bogardi, J., Canadell, J.G., Dhakal, S., Ingram, J., Leemans, R., Rosenberg, M., 2012. Responding to complex societal challenges: a decade of Earth System Science Partnership (ESSP) interdisciplinary research. Curr. Opin. Environ. Sustain. 4, 147-158.

Jasanoff, S., 2004. The idiom of co-production. In: Jasanoff, S. (Ed.), States of Knowledge. The Co-Production of Science and Social Order. Routledge, London/New York.

Jasanoff, S., Long Martello, M. (Eds.), 2004. Earthly Politics. Local and Global in Environmental Governance. The MIT Press, Cambridge.

Jasanoff, S., 2010. A new climate for society. Theory Cult. Soc. 27 (2-3), 233-253.

Latour, B., 1993. We Have Never Been Modern. Harvard University Press, Cambridge.

Latour, B., 2004. Politics of Nature. How to Bring Science into Democracy. Harvard University Press, Cambridge.

Litfin, K., 1997. The gendered eye in the sky: a feminist perspective on earth observation satellites. Frontiers 26-47.

Liverman, D.M., 2009. Conventions of climate change: constructions of danger and the dispossession of the atmosphere. J. Hist. Geogr. 35 (2), 279-296.

Lorimer, J., 2012. Multinatural geographies for the Anthropocene. Prog. Hum. Geogr. 36 (5), 593-612

Luke, T., 2009. Developing planetary accountancy: fabricating nature as stock, service and system for green governmentality. Curr. Perspect. Soc. Theory 26, 129-159.

Malm, A., Hornborg, A., 2014. The geology of mankind? A critique of the Anthropocene narrative. Anthropocene Rev. 1 (1), 62-69.

McKibbin, B., 1989. The End of Nature, 1st ed. Random House, New York. 
Moore, B.I., Underdal, A., Lemke, P., Loreau, M., 2002. The Amsterdam declaration on global change. In: Steffen, W., et, al. (Eds.), Challenges of a Changing Earth: Proceedings of the Global Change Open Science Conference. Springer-Verlag, New York.

O'Brien, K., 2012. Global environmental change III: closing the gap between knowledge and action. Prog. Hum. Geogr. 37 (4), 587-596.

O'Brien, K., Barnett, J., 2013. Global environmental change and human security. Annu. Rev. Environ. Resour. 38, 373-391.

Oldfield, F., Barnosky, T., Dearing, J., Fischer-Kowalski, M., McNeill, J., Steffen, W. Zalasiewicz, J., 2014. The anthropocene review: its significance, implications and the rationale for a new transdisciplinary journal. Anthropocene Rev. 1, 1-5.

Palsson, G., Szerszynski, B., Sörlin, S., Marks, J., Avril, B., Crumley, C., Hackmann, H. Holm, P., Ingram, J., Kirman, A., Pardo Buendia, B., Weehuizen, R., 2013. Reconceptualizing the 'anthropos' in the Anthropocene: integrating the social sciences and humanities in global environmental change research. Environ. Sci. Policy 28, 3-13.

Rockström, J., Steffen, W., Noone, K., Persson, Å., Chapin III, S., Lambin, E., Lenton, T.M., Scheffer, M., Folke, C., Schellnhuber, H.J., Nykvist, B., de Wit, C.A., Hughes, T., van der Leeuw, S., Rodhe, H., Sörlin, S., Snyder, P.K., Costanza, R., Svedin, U., Falkenmark, M., Karlberg, L., Corell, R.W., Fabry, V.J., Hansen, J., Walker, B., Liverman, D., Richardson, K., Crutzen, P., Foley, J.A., 2009. A safe operating space for humanity. Nature 461, 472-475.

Rockström, J., Brasseur, G., Hoskins, B., Lucht, W., Schellnhuber, J., Kabat, P. Nakicenovic, N., Gong, P., Schlosser, P., Máñez Costa, M., Humble, A., Eyre, N., Gleick, P., James, R., Lucena, A., Masera, O., Moench, M., Schaeffer, R., Seitzinger, S., van der Leeuw, S., Ward, B., Stern, N., Hurrell, J., Srivastava, L., Morgan, J., Nobre, C., Sokona, Y., Cremades, R., Roth, E., Liverman, D., Arnot, J., 2014. Climate change: the necessary, the possible and the desirable Earth League climate statement on the implications for climate policy from the 5th IPCC Assessment. Earth's Future 2, 606-611.

Rose, D.B., van Doorenb, T., Chrulewb, M., Cookec, S., Kearnesb, M., O'Gormand, E., 2012. Thinking through the environment, unsettling the humanities. Environ. Humanit. 1, 1-5.

Stafford-Smith, M., Gaffney, O., Brito, L., Ostrom, E., Seitzinger, S., 2012. Interconnected risks and solutions for a planet under pressure-overview and introduction. Curr. Opin. Environ. Sustain. 4, 3-6.

Steffen, W., Sanderson, A., Tyson, P.D., Jäger, J., Matson, P.A., Moore III, B., Oldfield, F., Richardson, K., Schellnhuber, H.J., Turner II., B.L., Wasson, R.J., 2004. Global
Change and the Earth System: A Planet under Pressure. Executive Summary International Geosphere-Biosphere Programme, Stockholm.

Steffen, W., Crutzen, P., McNeill, J.R., 2007. The Anthropocene: are humans now overwhelming the great forces of nature? AMBIO 36 (8), 614-621.

Steffen, W., Grinevald, J., Crutzen, P., McNeill, J., 2011a. The Anthropocene: conceptual and historical perspectives. Philos. Trans. R. Soc. A 369, 842-867.

Steffen, W., Persson, Å., Deutsch, L., Zalasiewicz, J., Williams, M., Richardson, K., Crumley, C., Crutzen, P., Folke, C., Gordon, L., Molina, M., Ramanathan, V., Rockstöm, J., Scheffer, M., Schellnhuber, H.J., Svedin, U., 2011b. The Anthropocene: from global change to planetary stewardship. AMBIO 40 (7), 739-761.

Steffen, W., Richardson, K., Rockström, J., Cornell, S.E., Fetzer, I., Bennett, E.M., Biggs, R., Carpenter, S., de Vries, W., de Wit, C.A., Folke, C., Gerten, D., Heinke, J., Mace, G.M., Persson, L.M., Ramanathan, V., Reyers, B., Sörlin, S., 2015. Planetary boundaries: guiding human development on a changing planet. Sci. Express $1-16$.

Stirling, A., 2011. Pluralising progress: from integrative transitions to transformative diversity. Environ. Innov. Soc. Transit. 1, 82-88.

Swyngedouw, E., 2013. The non-political politics of climate change. ACME 1-8

Swyngedouw, E., 2014. Anthropocenic politicization. From the politics of the environment to politicizing environments. In: Bradley, K., Hedrén, J. (Eds.) Green Utopianism. Perspectives, Politics and Micro-Practices. Routledge, London.

Tuhiwai Smith, L., 1999. Decolonizing Methodologies: Research and Indigenous Peoples. Zed Books, London.

Turnhout, E., Bloomfield, R., Hulme, M., Wynne, B., Vogel, J., 2012. Listen to the voices of experience. Nature 488, 454-455.

Uhrqvist, O., Lövbrand, E., 2014. Rendering global change problematic: the constitutive effects of Earth System research in the IGBP and the IHDP. Environ. Polit. 23 (2), 339-356.

Vitousek, P.M., Mooney, H.A., Lubchenko, J., Melillo, J.M., 1997. Human domination of the Earth's ecosystems. Science 227, 494-499.

Wakefield, S., 2014. The crisis is the age. Prog. Hum. Geogr. 12-14.

Wapner, P., 2014. The changing nature of nature: environmental politics in the Anthropocene. Glob. Environ. Polit. 14 (4), 36-54.

Whatmore, S.J., 2009. Mapping knowledge controversies: science, democracy and the redistribution of expertise. Prog. Hum. Geogr. 33, 587-698.

Zalasiewic, A., Williams, M., Steffen, W., Crutzen, P., 2010. The new world of the Anthropocene. Environ. Sci. Technol. 44, 2228-2231. 